\title{
HTC- May Survive in Bipolar World
}

\author{
Article history: \\ Received: 26 December 2015 \\ Sent for revision: 5 February 2016 \\ Received in revised form: 3 July 2016 \\ Accepted: 3 July 2016 \\ Available online: 8 October 2016
}

\begin{abstract}
The core assets of HTC are people, innovations, and technology. But in the recent quarters, HTC has started retrenching people even from $R \& D$ divisions which are responsible for innovation and developing new technologies. It means HTC's core assets are depleting. HTC was known for its cutting edge technology of $16 \mathrm{mp}$ camera and high speed '4G' technology but performing badly in the last two and half year. Why is it so? Paper objectives are to identify reasons for its downfall of HTC, distress signals for HTC downfall, and possible revival strategies for survival of HTC in Bipolar world (Samsung and Apple) of smartphones makers. In addition, research paper present eight research proposition/ questions with respect to present state of HTC and its future and possible answers to these research propositions/ questions. Research paper ends with concluding remarks in the context of HTC future.
\end{abstract}

Keywords: HTC, Android, Window, Innovation, Cutting edge technology, Bipolar World, Smartphone.

\section{Šanse HTC-a da preživi u bipolarnom svetu}

Apstrakt: Ljudi, inovacije i tehnologija su ključni resursi HTC-a. Međutim, u poslednjih nekoliko meseci, HTC je počeo da otpušta ljude čak iz sektora za istraživanje i razvoj koji su odgovorni za inovacije i razvoj novih tehnologija. To znači da se HTC-ovi ključni resursi osipaju. HTC je poznat po svojoj najsavremenijoj tehnologiji kamere od $16 \mathrm{MP}$ i 4G tehnologiji velike brzine, ali posluje loše u poslednje dve i po godine. Zbog čega je to tako? Cilj ovog rada je da identifikuje razloge pada u poslovanju HTC-a, znake koji upozoravaju na pad HTC-a i moguće strategije oživljavanja za opstanak HTC-a u bipolarnom svetu (Samsung i Apple) proizvođača pametnih telefona. Pored toga, u radu

\footnotetext{
${ }^{1}$ Management Development Institute, India, knpsingh@mdi.ac.in 
Singh N.P.: HTC-May Survive in Bipolar World

je predstavljeno osam istraživačkih pitanja u vezi sa sadašnjim stanjem HTCa i njegovom budućnošću kao i mogući odgovori na ova pitanja. Istraživački rad na kraju daje zaključak vezan za budućnost HTC-a.

Ključne reči: HTC, Android, Window, inovacije, najnovije tehnologije, bipolarni svet, pametni telefoni.

\section{Introduction}

In this competitive era, one cannot secure its brand, valuation and profitability for longer duration without investment in product innovation and designing appropriate business strategies. To mention, HTC, Taiwanese smartphone maker was the fourth biggest smartphone manufacturer during 2010 and 2011. HTC was also the first and biggest Android smartphone maker and the largest Window Mobile smartphone maker. Over the years, Samsung and Huawei have done much better with Android operating systems by devising better strategies and taken over HTC in all aspect. Windows Mobile operating system was a nightmare for smartphone makers such as Nokia. HTC was known for its cutting edge technology of $16 \mathrm{mp}$ camera and high speed '4G' technology and was not dependent on Windows Mobile OS. In spite of all, HTC did very badly in the last two and half year. HTC was valued at US $\$ 3.8$ billion at the end of Q2, 2013, down from US\$37 billion at its peak during 2010, a reduction of 10 times (Chawla (2014)). Its market cap was less than US\$ 1.5 billion in August 2015 which is much less than its market cap of US $\$ 28.4$ billion in 2010 (Riley (2015)). Its market share was around 10\% during peak years but it was 2\% in Q2 2015 (Beaver (2015)). Shah (2015) reported its market share even as $1.4 \%$ in smartphone domain during Q2, 2015.

Keeping in view the changing landscape of the smartphone market, this paper attempts to analyze the (i) reasons for the down fall of HTC, (ii) stress signals as a result of downfall of HTC, and (iii) possibilities of HTC revival in a market of low margins and fierce competition. The research paper also included a section of research methodology giving details of methodology and research questions. Subsequently, research paper presents answers to these research questions based on the analysis of qualitative and quantitative secondary data collected / compiled in the research paper. This data is with respect to (i) revenue, (ii) profits /losses, (iii) market share of HTC vis-à-vis of competitors, (iv) growth/reduction of number of employees, (v) factors responsible for growth and downfall of HTC, (vi) new product launch by HTC and associated positive and negative factors with these events, etc. 
Singh N.P.: HTC- May Survive in Bipolar World

\section{Research Methodology}

Research methodology of the research paper can be termed as exploratory in nature since it is based on secondary piecemeal data collected from many sources on the Internet specifically from the website of HTC, Gartner, and Statista. It contains sufficient amount of historical as well as current data which is sufficient to conclude or answer listed research questions/propositions. Therefore, methodology can be termed as exploratory cum descriptive in nature. The conclusions are drawn based on both qualitative and quantitative secondary data collected from the various sources mainly the Internet (websites of main stakeholders) as mentioned earlier. These conclusions need further examination with the availability of more data on the subject in near future specifically in relation to survival of HTC. The analysis of the research paper can be termed as similar to content analysis, event analysis, and trend analysis with respect to market share, revenue, and profitability. Analysis is an attempt to figure out (i) reasons of HTC downfall, (ii) stress signals to predict further downfall, (iii) suggestions for possible revival of HTC, and (iv) to generate possible answers to the following propositions/research questions of interest in the context of events linked to HTC.

Proposition/ Research Question 1: Will it be possible for HTC to survive in the face of recent downfall and fierce competition in the market?

Proposition/ Research Question 2: Does the size of home country markets matter for success of fast changing high technology products?

Proposition/ Research Question 3: High technology international market has place only for few successful international brands.

Proposition/ Research Question 4: High growth of a company in high tech domain results in to early downfall.

Proposition/ Research Question 5: Will expanded device (specifically mid range) portfolio help HTC in managing the confidence of the investors in near future?

Proposition/ Research Question 6: Lack of innovation by HTC is responsible for its downfall.

Proposition/ Research Question 7: Android's internal rivalry is responsible for its downfall.

Proposition/ Research Question 8: First mover advantage does not work always.

Further, research analysis included many events linked to HTC such as (i) laying off of the workforce and other problems, (ii) performance of HTC shares in Taiwan stock market, (iii) less expenditure on advertisement and product promotion, (iv) launching of new products and their acceptability among 
Singh N.P.: HTC-May Survive in Bipolar World

consumers in comparison to the new product launch by competitors, (v) discontinuation of partnership by technology partners, etc.

\section{Analysis of Growth and Downfall Statistics of HTC}

This section presents analysis of changing pattern in market share of mobile phone/smartphone major vendors in the world vis-à-vis share/ place/ ranking of HTC in market share. The analysis is based on quarterly as well as yearly data presented in tables 1(a), 1(b), 2(a), 2(b-1), 2(b-2), and 3.

\subsection{Yearly Analysis of Global market share of major mobile phones vendors by units (\%)}

Table 1(a) and table 1(b) present share of global market share by units in percentage of different mobile phone and smart phone manufacturers for the period starting with 2009 to 2015.

Table 1(a).Global Mobile Phones Market Share by Units, Percent (2009-2015)

\begin{tabular}{|c|c|c|c|c|c|c|c|}
\hline Vendors & $\begin{array}{c}2009 \\
{[1]}\end{array}$ & $\begin{array}{c}2010 \\
{[2]}\end{array}$ & $\begin{array}{c}2011 \\
{[3]}\end{array}$ & $\begin{array}{c}2012 \\
{[3]}\end{array}$ & $\begin{array}{c}2013 \\
{[4]}\end{array}$ & $\begin{array}{c}2014 \\
{[5]}\end{array}$ & $\begin{array}{c}2015 \\
{[6]}\end{array}$ \\
\hline Samsung & 19.5 & 17.6 & 17.7 & 22.0 & 24.6 & 20.9 & 19.9 \\
\hline Nokia & 36.4 & 28.9 & 23.8 & 19.1 & 13.9 & - & - \\
\hline Apple & 2.1 & 2.9 & 5.0 & 7.5 & 8.3 & 10.2 & 10.8 \\
\hline Microsoft & - & - & - & - & - & 9.9 & 6.2 \\
\hline Huawei & 1.1 & 1.5 & 2.3 & 2.7 & 2.9 & 3.8 & 5.9 \\
\hline LG Electronics & 10.1 & 7.1 & 4.9 & 3.3 & 3.8 & 4.0 & 4.0 \\
\hline Lenovo & - & - & - & - & 2.5 & $4.5^{\star}$ & $3.7^{\star}$ \\
\hline Xiaomi & - & - & - & - & - & 3.0 & 3.6 \\
\hline TCL Communication & - & - & 1.9 & 2.1 & 2.7 & 3.4 & 3.5 \\
\hline Motorola & 4.8 & 2.4 & 2.3 & 1.9 & & - & - \\
\hline HTC & 0.9 & 1.5 & 2.4 & 1.8 & & & \\
\hline Research in Motion & 2.8 & 3.0 & 2.9 & 2.0 & & & \\
\hline ZTE & 1.3 & 1.8 & 3.2 & 3.9 & - & 2.9 & 3.3 \\
\hline Micromax & - & - & - & - & - & 2.0 & 2.2 \\
\hline Sony & 4.5 & 2.6 & - & - & 2.1 & 2.0 & - \\
\hline Yulong & - & - & - & - & 1.8 & & \\
\hline Others & 16.5 & 30.6 & 33.6 & 33.6 & 34.0 & 33.5 & 36.9 \\
\hline Total & 100 & 100 & 100 & 100 & 100 & 100 & 100 \\
\hline
\end{tabular}

Source: [1] http://www.gartner.com/newsroom/id/1306513, [2] id/1543014, [3] id/2335616, [4] id/2665715, [5] id/2996817, [6] id/3115517: Note: * Lenovo + Motorola, 2015 data is for Q1,Q2.

The data is compiled from various reports of Gartner. It can be seen from the data that Nokia + Microsoft, HTC, Motorola, LG, and Research in Motion are 
Singh N.P.: HTC- May Survive in Bipolar World

losing their share in mobile phone market. The major gainers are Apple, Huawei, TCL communications, and ZTE. The number one manufacturer Samsung gained during 2012 and 2013 but during 2015 its share is almost at par with its share of 2009. It is also evident from the data of table 1(a) that aggregate share of small vendors is increasing and it was highest $(36.9 \%)$ during 2015. As far as HTC is concerned, Gartner is not showing its independent market share since 2013 as it is no more among the top five to six mobile phone manufacturers. It can be taken as a surrogate factor to the downfall of HTC.

Market share of smartphone makers is compiled in table 1(b). Aggregate share of Samsung, Apple, Huawei, Lenovo (Motorola) and Xiaomi is approximately $54 \%$. Till 2012 , HTC was a major vendor with $9.2 \%$ share and its ranking in market share was at third place. It had lost its place in the global smartphone market to Xiaomi, Huawei, and others. The data did not indicate very good scenario for Samsung as the share of small smartphone makers is increasing continuously and eating Samsung market maximum.

Table 1(b):Global Smartphone Market Share of Major Vendors by Units, Percent (2009-2015)

\begin{tabular}{|c|c|c|c|c|c|c|c|c|}
\hline Vendors & $\begin{array}{c}2009 \\
{[1]}\end{array}$ & $\begin{array}{c}2010 \\
{[1]}\end{array}$ & $\begin{array}{c}2011 \\
{[2]}\end{array}$ & $\begin{array}{c}2011 \\
{[3]}\end{array}$ & $\begin{array}{c}2012 \\
{[3]}\end{array}$ & $\begin{array}{c}2013 \\
{[4]}\end{array}$ & $\begin{array}{c}2014 \\
{[5]}\end{array}$ & $\begin{array}{c}2015 \\
{[6]}\end{array}$ \\
\hline Samsung & 4 & 8 & 19.1 & 18.7 & 30.8 & 31.0 & 24.7 & 21.9 \\
\hline Nokia & 39 & 34 & 15.7 & 15.9 & 5.0 & - & - & - \\
\hline Apple & 14 & 16 & 19.0 & 19.1 & 19.5 & 15.6 & 15.4 & 14.6 \\
\hline Huawei & - & - & - & 4.1 & 4.6 & 4.8 & 5.5 & 7.8 \\
\hline LG Electronics & 2 & 2 & - & 3.8 & 4.8 & 4.8 & 4.6 & - \\
\hline Lenovo & - & - & - & - & 3.6 & 4.5 & 6.5 & 5.0 \\
\hline Motorola & 5 & 4 & - & - & - & - & - & - \\
\hline Xiaomi & - & - & - & - & - & - & - & 4.9 \\
\hline HTC & 5 & 8 & 8.9 & 4.5 & 9.2 & - & - & - \\
\hline Research in & 21 & 16 & 10.4 & 10.8 & 4.8 & - & - & - \\
Motion & & & & & & & & \\
\hline ZTE & - & - & - & 2.5 & 4.3 & - & - & - \\
\hline Sony & 3 & 3 & - & 5.5 & 4.6 & - & - & - \\
\hline Others & 8 & 8 & 26.9 & - & 14.6 & 39.3 & 43.3 & 45.9 \\
\hline
\end{tabular}

Source: [1] http://www.quirksmode.org/blog/archives/2011/02/smartphone sale.html, [2] Mobithinking (2012), [3] Ahonen (2013), [4] http://www.gartner.com/newsroom/id/2665715, [5] id/2996817, [6]-id/3115517.

\subsection{Quarterly Analysis of Global market share of major mobile phones vendors by units (\%)}

Table 2(a), Table 2(b-1), Table 2(b-2), and table 3 contain quarterly data of sales of mobile phone and smartphones. Table 2 (a) contains quarterly data of 
Singh N.P.: HTC- May Survive in Bipolar World

global mobile phone market since Q1, 2012 to Q2, 2015. The Gartner news room is the source of data given in Table 2(a). It is evident from the data that HTC is not a top vendor in overall mobile phone market which is dominated by Samsung, Apple, Microsoft (Nokia), and other Chinese and Korean mobile phone vendors.

Table 2 (a): Quarterly Global Mobile Phone Market Share by Units, Percent (\%)(2012-15)

\begin{tabular}{|c|c|c|c|c|c|c|c|c|c|c|c|c|c|c|}
\hline Vendors & $\begin{array}{c}\mathrm{Q} 1 \\
2012 \\
{[1]}\end{array}$ & $\begin{array}{c}\mathrm{Q} 2 \\
{[2]}\end{array}$ & $\begin{array}{c}\mathrm{Q} 3 \\
23] \\
{[3]}\end{array}$ & $\begin{array}{c}\mathrm{Q} 4 \\
2012 \\
{[4]}\end{array}$ & $\begin{array}{c}\mathrm{Q} 1 \\
2013 \\
{[1]}\end{array}$ & $\begin{array}{c}\mathrm{Q} 2 \\
2013 \\
{[2]}\end{array}$ & $\begin{array}{c}\mathrm{Q} 3 \\
2013 \\
{[3]}\end{array}$ & $\begin{array}{c}\mathrm{Q} 4 \\
2013 \\
{[4]}\end{array}$ & $\begin{array}{c}\mathrm{Q} 1 \\
2014 \\
{[5]}\end{array}$ & $\begin{array}{c}\mathrm{Q} 2 \\
2014 \\
{[6]}\end{array}$ & $\begin{array}{c}\mathrm{Q} 3 \\
2014 \\
{[7]}\end{array}$ & $\begin{array}{c}\mathrm{Q} 4 \\
2014 \\
{[8]}\end{array}$ & $\begin{array}{c}\mathrm{Q} 1 \\
2015 \\
{[5]}\end{array}$ & $\begin{array}{c}\mathrm{Q} 2 \\
2015 \\
{[6]}\end{array}$ \\
\hline Samsung & 21.1 & 21.5 & 22.7 & 22.0 & 23.6 & 24.7 & 25.7 & 24.6 & 24.5 & 21.9 & 20.6 & 20.9 & 21.3 & 19.9 \\
\hline Nokia & 19.7 & 19.9 & 19.1 & 19.1 & 14.8 & 14.0 & 13.8 & 13.9 & - & - & - & - & - & - \\
\hline Apple & 7.8 & 6.9 & 5.7 & 7.5 & 9.0 & 7.3 & 6.7 & 8.3 & 9.6 & 8.0 & 8.4 & 10.2 & 13.1 & 10.8 \\
\hline Microsoft & - & - & - & - & - & - & - & - & 11.1 & 9.9 & 9.5 & 9.9 & 7.2 & 6.2 \\
\hline Huawei & 2.6 & 2.6 & 2.8 & 2.7 & 2.6 & 2.6 & 3.0 & 2.9 & 3.2 & 4.1 & 3.6 & 3.8 & 4.0 & 5.9 \\
\hline LG Elec. & 3.5 & 3.4 & 3.2 & 3.3 & 3.7 & 3.9 & 4.0 & 3.8 & 3.3 & 4.1 & 4.2 & 4.0 & 4.3 & 4.0 \\
\hline Lenovo & 1.4 & 1.6 & 1.7 & 1.6 & 1.8 & 2.5 & 2.9 & 2.5 & $3.9^{*}$ & $4.3^{*}$ & 3.3 & $4.5^{*}$ & $4.2^{*}$ & $3.7^{*}$ \\
\hline Xiaomi & - & - & - & - & - & - & - & - & 2.1 & 2.8 & 3.5 & 3.0 & 3.2 & 3.6 \\
\hline $\begin{array}{c}\text { TCL } \\
\text { Comm. }\end{array}$ & 1.7 & 2.2 & 2.2 & 2.1 & 2.0 & 2.3 & 2.7 & 2.7 & 2.7 & 3.1 & 3.5 & 3.4 & 3.1 & 3.5 \\
\hline ZTE & 4.1 & 4.1 & 3.9 & 3.9 & 3.4 & 3.5 & 3.0 & 3.3 & 3.1 & 2.8 & 3.0 & 2.9 & 2.7 & 3.3 \\
\hline Micromax & - & - & - & - & - & - & - & - & 1.7 & 1.9 & 2.2 & 2.0 & 1.8 & 2.2 \\
\hline Sony & 1.9 & 1.7 & 1.9 & 1.8 & 1.9 & 2.2 & 2.1 & 2.1 & - & - & - & - & - & - \\
\hline Yulong & - & - & - & - & 1.8 & 1.8 & 1.9 & 1.8 & - & - & - & - & - & - \\
\hline
\end{tabular}

Source: [1] http://www.gartner.com/newsroom/id/2482816, [2] id/2573415, [3] id/2623415, [4] id/2665715, [5] id/3061917, [6] id/3115517, [7] id/2944819, [8] id/2996817.

Table 2 (b-1): Quarterly Global Smartphone Mobile Market Share by Units (\%) from Q2, 2013 to Q3, 2015.

\begin{tabular}{|c|c|c|c|c|c|c|c|c|c|c|}
\hline Vendors & $\begin{array}{c}\text { Q2 } \\
2013 \\
{[1]}\end{array}$ & $\begin{array}{c}\text { Q3 } \\
2013 \\
{[2]}\end{array}$ & $\begin{array}{c}\text { Q4 } \\
2013 \\
{[3]}\end{array}$ & $\begin{array}{c}\text { Q1 } \\
2014 \\
{[4]}\end{array}$ & $\begin{array}{c}\text { Q2 } \\
2014 \\
{[5]}\end{array}$ & $\begin{array}{c}\text { Q3 } \\
2014 \\
{[6]}\end{array}$ & $\begin{array}{c}\mathrm{Q} 4 \\
2014 \\
{[7]}\end{array}$ & $\begin{array}{c}\text { Q1 } \\
2015 \\
{[4]}\end{array}$ & $\begin{array}{c}\mathrm{Q} 2 \\
2015 \\
{[5][8]}\end{array}$ & $\begin{array}{c}\text { Q3 } \\
2015 \\
{[8]}\end{array}$ \\
\hline Samsung & 31.7 & 32.1 & 29.5 & 30.4 & 26.2 & 24.4 & 19.9 & 24.2 & $21.9(26.7)$ & 24.6 \\
\hline Apple & 14.2 & 12.1 & 17.8 & 15.3 & 12.2 & 12.7 & 20.4 & 17.9 & $14.6(15.4)$ & 13.7 \\
\hline Huawei & & 4.7 & 5.7 & 4.8 & 6.1 & 5.3 & 5.7 & 5.4 & $7.8(7.5)$ & 8.4 \\
\hline LG & 5.1 & 4.8 & 4.5 & 4.0 & & & & 4.6 & & \\
\hline Lenovo & 4.7 & 5.1 & 4.6 & $5.9^{*}$ & $6.6^{*}$ & 5.0 & $6.6^{\star}$ & $5.6^{*}$ & $5.0^{*}(5.2)$ & $5.7^{\star}$ \\
\hline Xiaomi & - & - & - & - & 4.3 & 5.2 & 5.1 & & $4.9(5.9)$ & 5.7 \\
\hline ZTE & 4.3 & - & - & - & - & - & - & - & - & \\
\hline Others & 40.0 & 41.1 & 37.9 & 39.7 & 44.6 & 47.5 & 42.4 & 42.4 & $45.9(39.2)$ & 41.8 \\
\hline
\end{tabular}

Source: [1] http://www.gartner.com/newsroom/id/2573415, [2] id/2623415, [3] id/2665715, [4] id/3061917, [5] id/3115517, [6] id/2944819, [7] id/2996817, [8] Vince (2015)

Table 2(b-1) presents data with respect to global smartphone market share (in percentage) of major vendors from Q2 2013 TO Q3 2015. The major source of data in this case also Gartner newsroom. It can be seen from the 
Singh N.P.: HTC- May Survive in Bipolar World

data given in table 2(b-1) that HTC could not find place in first top five vendors. Market is dominated by Samsung, Apple, Huawei, Lenovo and Xiaomi. If one adds the market share of Huawei, Lenovo and Xiaomi, it is at par with Samsung. This is another proof of downfall of HTC and emergence of Chinese makers. Data is collected from different sources for few quarters and have large variations in some cases as evident from the data for Q2, 2015.

Data given in table 2(b-2) is also about global smartphone market share of major vendors from Q4, 2009 to Q3, 2015 but from only one source. There are two objectives for inclusion of this data. First to infer that till Q2, 2012 HTC was one of the major vendors since its market share was reported separately by research companies. After that it has lost its share and was included in the category of others. Second objective was to communicate that data from different sources vary for the same period but trends remains the similar.

Table 2 (b-2): Global Smartphone Market Share by Vendors (\%age) from Q4 2009 to Q3 2015

\begin{tabular}{|c|c|c|c|c|c|c|c|c|c|c|c|c|}
\hline Vendors & Samsung & Apple & LG & Lenovo & ZTE & Huawei & Xiaomi & Sony & RIM & HTC & Nokia & Others \\
\hline Q4 2009 & 3.3 & 16.1 & - & - & - & - & - & - & 19.9 & 4.5 & 38.6 & 17.6 \\
\hline Q1 2010 & 4.3 & 15.7 & - & - & - & - & - & - & 19.1 & 4.9 & 38.8 & 17.2 \\
\hline Q2 2010 & 5.6 & 13 & - & - & - & - & - & - & 17.4 & 6.8 & 37.3 & 19.9 \\
\hline Q3 2010 & 8.8 & 17 & - & - & - & - & - & - & 15 & 7.1 & 32 & 20.1 \\
\hline Q4 2010 & 9.4 & 15.9 & - & - & - & - & - & - & 14.3 & 8.5 & 27.6 & 24.3 \\
\hline Q1 2011 & 11.3 & 18.3 & - & - & - & - & - & - & 13.6 & 8.9 & 23.8 & 24.1 \\
\hline Q2 2011 & 17.0 & 18.8 & - & - & 1.8 & - & - & - & 11.5 & 10.7 & 15.4 & 24.8 \\
\hline Q3 2011 & 22.7 & 13.8 & - & - & 3.3 & - & - & - & 9.6 & 10.3 & 13.6 & 26.7 \\
\hline Q4 2011 & 22.5 & 23 & - & - & 4 & 3.5 & - & 3.9 & 8.1 & 6.4 & 12.2 & 16.4 \\
\hline Q1 2012 & 28.8 & 23 & 3.2 & - & 4 & 3.3 & - & 3.6 & 6.4 & 4.5 & 7.8 & 15.4 \\
\hline Q2 2012 & 32.2 & 16.6 & 3.7 & 3.1 & 4.1 & 4.1 & - & 4.7 & 4.9 & 5.9 & 6.6 & 14.0 \\
\hline Q3 2012 & 31.0 & 14.4 & 3.8 & 3.7 & 4.4 & 3.8 & - & 4.7 & 4.3 & 4 & - & 25.7 \\
\hline Q4 2012 & 29.1 & 20.9 & 3.8 & 4.1 & 4.4 & 4.6 & - & 4.5 & - & - & - & 28.6 \\
\hline Q1 2013 & 31.9 & 17.1 & 4.7 & 3.6 & 4.2 & 4.3 & - & - & - & - & - & 33.8 \\
\hline Q2 2013 & 32.3 & 13 & 5 & 4.7 & 4.2 & 4.3 & - & - & - & - & - & 36.4 \\
\hline Q3 2013 & 32.5 & 12.9 & 4.6 & 4.7 & - & 4.7 & 2.1 & - & - & - & - & 38.4 \\
\hline Q4 2013 & 28.83 & 17.43 & 4.6 & 4.51 & - & 5.66 & 2.03 & - & - & - & - & 36.94 \\
\hline Q1 2014 & 30.7 & 15.2 & 4.3 & 4.4 & - & - & 4.7 & - & - & - & - & 40.8 \\
\hline Q2 2014 & 24.8 & 11.7 & 4.9 & 5.2 & - & 6.7 & 4.6 & - & - & - & - & 42.1 \\
\hline Q3 2014 & 23.9 & 11.8 & 5.1 & 5.1 & - & 5.0 & 5.2 & - & - & - & - & 43.9 \\
\hline Q4 2014 & 20.01 & 19.85 & - & 6.59 & - & 6.25 & 4.42 & - & - & - & - & 42.9 \\
\hline Q1 2015 & 24.5 & 18.2 & 4.6 & 5.6 & - & 5.0 & - & - & - & - & - & 42.1 \\
\hline Q2 2015 & 21.7 & 14.1 & - & 4.8 & - & 8.9 & 5.3 & - & - & - & - & 45.2 \\
\hline Q3 2015 & 23.8 & 13.5 & - & 5.3 & - & 7.5 & 5.2 & - & - & - & - & 44.8 \\
\hline
\end{tabular}

Source: Statista(2015). $\quad$ http://www.statista.com/statistics/271496/global-market-share-held-bysmartphone-vendors-since-4th-quarter-2009/

The data presented in table 3 is about number of smartphone shipments in thousands. The data of table 3 has four unique features, i.e., (i) research companies are reporting data of only five popular vendors rests are clubbed 
Singh N.P.: HTC-May Survive in Bipolar World

together, (ii) number of shipped units are not increasing continuously but declining in between on quarterly basis, (iii) maximum numbers of units are shipped in the year closing fourth quarter for each year, (iv) first two quarters of 2015 recorded a sharp decline in the number of units shipped, and (v) HTC is not reported separately but with others.

Table 3: Global Smartphone Shipments 1Q, 2012-2Q, 2015 (figure in Thousands of Units)

\begin{tabular}{|c|c|c|c|c|c|c|c|c|}
\hline $\begin{array}{c}\text { Quarter / } \\
\text { Year }\end{array}$ & Samsung & Apple & $\begin{array}{c}\text { Lenovo+ } \\
\text { Moto }\end{array}$ & Huawei & LG & Xiaomi & Others & Total \\
\hline 1Q 2012 [1] & $40,612.8$ & $33,120.5$ & - & $5,269.6$ & $4,961.4$ & - & $63,055.9$ & $147,020.2$ \\
\hline 2Q 2012 [2] & 45603.8 & $28,935.0$ & $4,370.9$ & - & $5,827.8$ & - & $69,035.4$ & $153,772.9$ \\
\hline 3Q 2012 [3] & $55,054.2$ & $24,620.3$ & $6,981.0$ & $7,804.3$ & $6,986.1$ & - & $70,206.8$ & $171,652.7$ \\
\hline 4Q 2012 [4] & $64,496.3$ & $43,457.4$ & $7,904.2$ & $8,666.4$ & $8,038.8$ & - & $75,099.3$ & $207,662.4$ \\
\hline 1Q 2013 [1] & $64,740.0$ & $38,331.8$ & - & $9,334.2$ & $10,080.4$ & - & 87559.7 & $210,046.1$ \\
\hline 2Q 2013 [2] & $71,380.9$ & $31,899.7$ & $10,671.4$ & - & $11,473.0$ & - & 99901.2 & $225,326.2$ \\
\hline 3Q 2013 [3] & $80,356.8$ & $30,330.0$ & $12,882.0$ & $11,665.7$ & $12,055.4$ & - & $102,941.8$ & $250,231.7$ \\
\hline 4Q 2013 [4] & $83,317.2$ & $50,224.4$ & $12,892.2$ & $16,057.1$ & $12,822.9$ & - & $106,937.9$ & $282,251.7$ \\
\hline 1Q 2014 [5] & $85,507.0$ & $43,062.0$ & $16,721.0$ & $13,450.0$ & $11,200.0$ & - & $111,697.8$ & $281,636.8$ \\
\hline 2Q 2014 [6] & $76,129.2$ & $35,345.3$ & $19,081.2$ & $17,657.7$ & - & $12,540.8$ & $129,630.2$ & $290,384.4$ \\
\hline 3Q 2014 [7] & $73,212.4$ & $38,186.6$ & $15,011.9$ & $15,934.9$ & - & $15,772.5$ & $142,891.6$ & $301,009.9$ \\
\hline 4Q 2014 [8] & $73,032.0$ & $74,832.0$ & $24,300.0$ & $21,038.0$ & - & $18,582.0$ & $155,701.6$ & $367,484.5$ \\
\hline 1Q 2015[5] & $81,123.0$ & $60,177.0$ & $18,888.0$ & $18,102.0$ & $15,428.0$ & - & $142,335.6$ & $336,054.4$ \\
\hline 2Q 2015 [6] & $72,072.5$ & $48,085.5$ & $16,405.9$ & $25,825.8$ & - & $16,064.9$ & $151,221.7$ & $329,676.4$ \\
\hline
\end{tabular}

Source: [1] http://www.gartner.com/newsroom/id/2482816, [2] id/2573415, [3] id/2623415, [4] id/2665715, [5] id/3061917, [6] id/3115517, [7] id/2944819, [8] id/2996817.

\section{Reasons of HTC downfall}

HTC has made investment to innovate software as well as hardware for its business growth. Its strategies look much better than Nokia which has decided to sell off its mobile handset business (Singh(2014)). HTC is never stagnant and incompetent. It is introducing new features regularly but still could not sustain competition due to some miscalculations and many a times not reacted as per the needs. HTC leadership has accepted the mistakes and challenges and has not given up its efforts to comeback as evident from statements of leadership. Many reasons such as glitches in supply chain, inappropriate marketing efforts, overpricing of tablets and other devices, lack of innovation in design, selecting sub standard processor, and market dynamics are cited by the experts for the downfall of the HTC. Some specific reasons for its downfall as reported in the recent two years by experts are listed in the following:

Reason 1:Supply Chain Management: AP (2015) reported that marketing and supply chain glitches as well as intense competition from Apple, 
Singh N.P.: HTC- May Survive in Bipolar World

Samsung Electronics and Chinese makers such as Xiaomi is one of the reason for its downfall.

Reason 2: Contracting Carriers: Samsung and Apple captured the United States through sales contracts with wireless carriers which HTC could do it but was not effective (AP(2015)). However, HTC could sale 5-inch HTC Droid DNA through US carrier Verizon Wireless (Taipeitimes (2013)).

Reason 3: Competing in China: HTC could not compete with Lenovo and Xiaomi in China in creating a good customer base (AP (2015)). Experts have reported additional factors for HTC decline. These factors are (i) less demand for high-end Android devices, and (ii) less sales in china than the forecasted figures (Boxell (2015)). Xiaomi and Samsung had ruined early advantages of HTC in China (Millward (2015)).

Reason 4:Marketing Efforts: HTC spent less in marketing, perhaps underestimated the impact of the iconic name recognition of Apple and aggressive publicity campaigns by Samsung(AP (2015)). HTC is out marketed by Samsung with huge marketing budget (Millward 92015)). HTC tried to enhanced its marketing efforts by splashing out $\$ 1 \mathrm{bn}$ on a marketing campaign starring Robert Downey Jr during 2013 for HTC One M7. Commercial ads featuring Gary Oldman did not help in advertising the company's flagship smartphone during 2014 according to Sivanandan (2014). All these marketing efforts are of no use. Late of, HTC start thinking that the competition has raised operating costs as well as cost for product promotion and decided to invest less (Boxall (2015)).

Reason 5: Advertisement and its impact: The ads were lacking right strategy. To mention, the ads for HTC One M9 could not communicate all features of the smart phone to the market (Amadeo (2015)). Another expert Sivanandan (2014) reported that HTC had failed to uplift its market performance due to its inadequate marketing strategies for its feature-rich smartphones.

Reason 6: Lack of Components parts: HTC moved slowly in securing smartphone components such as processor while competition was growing much faster (AP (2015)). De Guzmen (2013) reported that HTC ran short of Aluminum body of the HTC flagship HTC One which led to delay in production and secondly it was not ready on the date of release. On the other hand, Samsung Galaxy S4 was becoming a hit in the market at the same time.

Reason 7: Lack of Innovation in Design and patent issues: HTC could not create better designs and could not add other product features in comparison to Samsung and Apple (Amadeo (2015)). To mention, HTC One M9 holds onto a microSD card slot with memory up to $200 \mathrm{~GB}$. On the other hand, Samsung's Galaxy line abandoned the microSD card slot and increased the internal memory though it was less than $200 \mathrm{~GB}$. It is being received highly 
Singh N.P.: HTC- May Survive in Bipolar World

positively in the market and made Samsung a better innovator in comparison to HTC (Barrett (2015)). Further, HTC had patents infringement issues with Apple and Nokia. HTC had to pay royalties to Nokia (Decker and Wang (2014)).

Reason 8: Qualcomm Snapdragon 810 SoC: HTC One M9 was upgraded with Qualcomm Snapdragon 810 SoC. The chip turned out to be hot and throttled very quickly. It wasn't much of an upgrade over 2014 devices. The heat and throttling reports also made consumers wary of Snapdragon 810devices (Amadeo (2015)). It was not a good decision on part of HTC though chip was rated positively by the reviewer.

Reason 09: Low Margin for Android Mobile Phone Makers: Edwards (2015) quoted that Android business is very brutal. Its phone manufacturers make an average profit of only 1.2 cents per phone. It means economy of scale is very important for a smartphone maker to survive. Hruska (2015) reported that manufacturers like LG, with its well-received G3 and G4 family, tend to make around 1 cent per phone in net profit. Low margins and decline market share contributed significantly in the downfall of HTC.

Reason 10: Pricing of Nexus 9 and Other Smartphones: Nexus 9 runs with Lollipop OS was an overpriced tablets by HTC. Further its build quality was poor as mentioned by Amadeo (2015). Its NVIDIA's K1 chipset made it a serious contender among tablets of different makers but price and other negative points reported by reviewers impacted its acceptability in the market. HTC also priced its handsets higher than the similar handsets of the competitors with better hardware in some cases. Millward (2015) reported that HTC was beaten by competitors with respect to specification in top end domain and on prices in the budget range segment of smart phones.

Reason 11: Market Dynamics: Barrett (2015) reported that there was nothing wrong with HTC as such but smartphone market doesn't have room for more than a handful of smartphone makers. If one does not innovate and is not different then it can no longer hope for much. Millward (2015) said that HTC peak came before the peak of smartphone market. It means HTC exhausted its energy before time.

Reason 12: Android's Internal Rivalry: Nicole (2012) reported that Android internal rivalry is also one of the reasons for downfall of HTC. HTC was unable to sustain competition among Android OEMs. Nicole (2012) also mentioned that third-party software, such as ad servers or analytics systems (adware) was reported as malware in Symantec report and CarrierlQ. Google has been addressing some of these problems but it is impacting likes of HTC more. 
Singh N.P.: HTC- May Survive in Bipolar World

\section{Distress Signals of HTC indicating downfall}

The common distress signals for the industry in any segments are laying off of the workforce, reaction of stock markets, selling off the assets, falling revenue, falling popularity of the products, and few more. The important stress signals in the context of HTC are listed in the following

(i) Laying off: AP (2015) mentioned that HTC announced a 15\% cut in its staff of about 15,700 after a second-quarter loss of $\$ 247$ million. Liu (2015) quoted that HTC is laying off 600 workers in Taiwan. He further reported that layoff will concentrate on the R\&D department and production lines in Taiwan which in turn will impact innovation. Malik (2013) quoted that HTC's chief product manager has resigned and some seniors are leaving company. Griffith (2013) reported that three designer of HTC were arrested in Taipei. It all impacted the morale of employees. The details of HTC staff in different categories by HTC are presented in table 4. It can be seen from table 4 that HTC has given due importance to specialists but few lay offs had sent wrong signals in the market.

Table 4: Category wise statistics of HTC employees from 2006 to 2015

\begin{tabular}{|c|c|c|c|c|c|}
\hline Year & Management & Specialists & Administrators & Technical Staff & Total \\
\hline 2006 & 262 & 1211 & 263 & 2854 & 4590 \\
\hline 2007 & 334 & 1998 & 348 & 2889 & 5569 \\
\hline 2008 & 591 & 2718 & 646 & 5398 & 9353 \\
\hline 2009 & 563 & 2732 & 626 & 4328 & 8249 \\
\hline 2010 & 874 & 2978 & 931 & 7792 & 12575 \\
\hline 2011 & 1317 & 4010 & 1240 & 10846 & 17413 \\
\hline 2012 & 1473 & 3623 & 1280 & 11199 & 17575 \\
\hline 2013 & 1514 & 3929 & 1338 & 12471 & 19252 \\
\hline 2014 & 1438 & 3671 & 1219 & 10572 & 16900 \\
\hline 2015 & 1398 & 3752 & 1217 & 9318 & 15685 \\
\hline (March 31) & & &
\end{tabular}

Source: http://media.corporate-ir.net/media files/IROL/ (Annual Report of the years$2008,2010,2012,2014,2015)$

(i) Removal from blue chip index of Taiwan Exchange: AP (2015) reported that HTC was removed from FTSE TWSE Taiwan 50 index on August 21, 2015. It was highly negative news for HTC and had impacted its market performance.

(ii) Share Price less than the Cash at Hand: Barrett (2015) and Kessler (2015) reported that company is worthless to the investors. During June 2015 with share price of $\$ 1.82 /$ share at Taiwan Stock Exchange, its market cap was $\$ 1.34$ billion. On the 
Singh N.P.: HTC-May Survive in Bipolar World

other hand, as per the HTC's balance sheet at the end June 2015 , HTC's total assets of $\$ 4.9$ billion including $\$ 1.5$ billion cash minus $\$ 2.6$ billion debt liabilities. It means still company value was $\$ 2.3$ billion but this value was not accepted by markets.

(iii) Selling off Manufacturing facilities: Liu (2015) reported that HTC is selling off two manufacturing facilities in Shanghai. He further reported that Shanghai manufacturing units have been closed for a month and that 500-600 people, mostly production line personnel, left their posts by the end of August. Only 20-30 supervisors are left. However, there is no change in R\&D department and sales department. This again impacted the reputation of the company.

(iv) Falling Revenue: Domanico (2012) reported that HTC 4Q, 2012 revenues were $\mathrm{U} \$ 3.48$ billion (102.4 billion Taiwanese dollars) with earnings per share (EPS) of US $\$ 0.44$ (13.06 Taiwanese Dollars). It is far below the estimates of 144.6 billion Taiwanese dollars, and EPS of 17.03. HTC has to revise its revenue for next quarter. Data presented Table $6(\mathrm{a})$, and $6(\mathrm{~b})$ is a proof of its falling revenues.

(v) Declining popularity of the new Product: HTC One (M8) was estimated to sell 3 to 5 million units in Q2 of 2014. Samsung shipped 10 million Galaxy S4 smartphones in just one month of 2013 and Apple sold 9 million iPhones in one weekend in 2013 (Epstein(2014b)). It indicate that market potential of HTC One (M8) was not very positive among top executives. Malik (2013) quoted that HTC First which was launched in partnership with Facebook was flop. These statistics indicate declining popularity of HTC smartphones.

(vi) Discontinuation in Partnerships: Griffith (2013) mentioned that HTC was ditched by Dr Dre's headphone company Beats, which bought out HTC's stake and ended their partnership.

\section{Analysis of HTC Units Sold}

The details of the quarterly units sold by HTC are presented in table 5(a) from Q1 2010 to Q3 2012. It is evident from the data given in table 5(a) that year 2010 was growth year for HTC. Brian (2010) reported that HTC had launched two new Android-powered smartphones, the Desire HD and the Desire Z. HTC has also released four new Windows Phone 7 handsets, i.e., the Mozart, Surround, Trophy and the HD7 during the year. Year 2011 was also a growth 
Singh N.P.: HTC- May Survive in Bipolar World

year for HTC. Year 2012 has seen beginning of the downfall of HTC. More data is not available for HTC with respect to its share in mobile phone market. The source of data was mainly Statista web site.

Table5(a): No of HTC units sold (in Millions) and its share in mobile market

\begin{tabular}{|c|c|c|c|}
\hline Quarter/Year & Units sold & $\begin{array}{c}\text { Market Share } \\
(\%)\end{array}$ & Source \\
\hline Q1 2010 & 3.38 & 1.60 & (Statista 2015a) (Statista 2015b) \\
\hline Q2 2010 & 5.91 & 1.80 & (Statista 2015a) (Statista 2015b) \\
\hline Q3 2010 & $6.49 / 7.00$ & $1.60 / 1.73$ & (Statista 2015a) (Statista 2015b), Brian (2010) \\
\hline Q4 2010 & 8.91 & 2.00 & (Statista 2015a) (Statista 2015b) \\
\hline Q1 2011 & 9.31 & 2.2 & (Statista 2015a) (Statista 2015b) \\
\hline Q2 2011 & 11.02 & 2.6 & (Statista 2015a) (Statista 2015b) \\
\hline Q3 2011 & 12.10 & 2.7 & (Statista 2015a) (Statista 2015b) \\
\hline Q4 2011 & 10.84 & 2.3 & (Statista 2015a) (Statista 2015b) \\
\hline Q1 2012 & 7.70 & 1.8 & (Statista 2015a) (Statista 2015b) \\
\hline Q2 2012 & 9.30 & 2.2 & (Statista 2015a) (Statista 2015b) \\
\hline Q3 2012 & 8.43 & 2.0 & (Statista 2015a) (Statista 2015b) \\
\hline
\end{tabular}

Source: Statista (2015a): http://www.statista.com/statistics/216517/global-market-share-of-htc/ Statista (2015b): http://www.statista.com/statistics/263355/global-mobile-device-sales-by-vendorsince-1st-quarter-2008/

Table 5(b) consists of data with respect to smartphones.

Table 5 (b): No of HTC units sold (in Millions) and its share in smartphone mobile market

\begin{tabular}{|c|c|c|c|}
\hline Quarter/Year & Units sold & Market Share (\%) & Source \\
\hline 2009 & 11.70 & - & Gsmarena (2011a) \\
\hline Q3 2010 & 6.49 & 1.56 & Aurthur (2010) \\
\hline Q4 2010 & 9.10 & - & Gsmarena (2011a) \\
\hline 2010 & $24.6 / 25.0$ & $8.30 / 8.44$ & Ahonen (2013), Epstein (2010) \\
\hline Q1 2011 & 9.0 & 8.9 & Sridhar (2012) \\
\hline Q3 2011 & 13.10 & 10.9 & Canalys (2012) \\
\hline 2011 & 44.60 & 9.2 & Ahonen (2013) \\
\hline Q1 2012 & 6.9 & 4.8 & Sridhar (2012) \\
\hline Q2 2012 & 8.8 & 5.7 & Blandford and Leitchfield (2012) \\
\hline Q3 2012 & 8.40 & 4.8 & Canalys (2012) \\
\hline Q4 2012 & 7.00 & 3.2 & Ahonen (2013) \\
\hline 2012 & 31.50 & 4.5 & Ahonen (2013) \\
\hline Q12013 & 9.90 & 3.10 & Taipeitimes (2013) \\
\hline Q2 2013 & $5.00 / 7.10$ & 2.90 & Russell (2013) \\
\hline Q3 2013 & 6.60 & 2.40 (Cal) & Mynewsdesk (2013)/ Shah (2014) \\
\hline Q4 2013 & 7.40 & 2.60 & Ahonen (2014) \\
\hline 2013 & 26.6 & 2.70 & Ahonen (2014) \\
\hline Q1 2014 & 3.10 & 1.04 & $\mathrm{Ku}(2014 \mathrm{~b})$ \\
\hline Q2 2014 & $5.8 / 6.9$ & 2.30 & Ku (2014b)/Counterpoint (2014) \\
\hline Q3 2014 & 8.25 & 2.50 & Ahonen (2014) \\
\hline
\end{tabular}




\section{Singh N.P.: HTC- May Survive in Bipolar World}

It can be seen that from the data of table $5(\mathrm{a})$ and table $5(\mathrm{~b})$ that $\mathrm{HTC}$ share is much higher in smartphone market in comparison to mobile phone market. HTC is a smartphone company. The data is collected from large number of sources, therefore, data may have inconsistencies. Canalys (2012) reported that HTC stayed in fourth place, with just under $5 \%$ of the market in Q3 of 2012. The popular devices during this period were iPhone 5, HTC One series \& Desire V and Samsung Galaxy S3. It was further reported that HTC has had strong sequential growth in major developing markets, such as China and Indonesia but Q4 2012 is going to be tough for HTC. In fact it was. Year 2013 has seen more downfalls of HTC and market research companies and researchers are not presenting HTC data separately but started clubbing it with others. Mynewsdesk (2013) quoted that HTC needs to create a better portfolio to survive rather than few good devices.

Table 5๑ consists of data with respect to domestic and international (export) sales in million units. The main source of data is annual reports of HTC. From the analysis given in table $5 \odot$ it can be inferred that HTC is losing market share in domestic as well as international market. In fact, HTC is losing more in domestic market. HTC needs to devise better strategies for product portfolio, marketing, pricing, quality, and retention of employees so that their morale remains high.

Table 5 (c): HTC Smart phone and other items unit sales (Domestic and International) (in Millions)

\begin{tabular}{|c|c|c|c|c|c|}
\hline Year & Domestic & Change $(+/-) \%$ & International & Change $(+/-) \%$ & Source \\
\hline 2006 & 0.43 & 0.00 & 27.6 & 0.00 & Annual Report 2006 \\
\hline 2007 & 0.43 & 0.00 & 48.2 & 74.63 & Annual Report 2007 \\
\hline 2008 & 0.39 & -9.30 & 36.9 & -23.44 & Annual Report 2008 \\
\hline 2009 & 1.36 & 248.72 & 45.5 & 23.31 & Annual Report 209 \\
\hline 2010 & 4.72 & 247.72 & 79.3 & 74.28 & Annual Report 2010 \\
\hline 2011 & 12.63 & 167.58 & 146.9 & 85.24 & Statista (2015) \\
\hline 2012 & 7.54 & -40.30 & 139.1 & -5.31 & Annual Report 2012 \\
\hline 2013 & 3.02 & -59.95 & 97.2 & -30.12 & Annual Report 2013 \\
\hline 2014 & 2.15 & -28.81 & 82.2 & -15.43 & Annual Report 2014 \\
\hline
\end{tabular}

\subsection{HTC Revenues and Profits:}

Data with respect to quarterly revenue and profits/losses are given in table 6(a). It can be seen from the data given in table 6(a) that HTC observed losses first time in $3^{\text {rd }}$ quarter of 2013. It is followed by losses during Q1 2014, Q2 2015, and Q3, 2015. For other quarters of 2010 to 2015, HTC recorded profits. The reasons cited by different industry experts are as under: 
Singh N.P.: HTC- May Survive in Bipolar World

\begin{abstract}
Year 2010
Malik (2010) reported that HTC is winning because Android OS. In December 2009, HTC launched seven Android OS phones and eight Window OS phones. Gsmarena (2010) reported that EPS of 0.2 US $\$$ which was higher than the expectation of the company during Q1,2010 but its camera received bit negative feedback from the market. Kendrick (2010) reported that an increase in HTC revenue and profits are because of HTC Dream, HTC Hero and HTC Magic smartphones and Android OS during Q2, 2010. Savov (2010) quoted Android again as the chief catalyst for this growth of HTC revenue (US\$2.45 billion) and profit (US\$ 360 million) during Q3, 2010. Company has seen an EPS of NT\$13.69 during the period. Gsmarena (2011a) reported very good performance during Q4, 2010 and quoted that HTC will focus on $4 G$ devices. It is also reported that HTC's six new devices and a tablet is waiting to hit market during 2011. HTC recorded NT\$ 18.61 EPS during Q4,2010. Big portfolio of product was reported during the year as important factor for success.
\end{abstract}

\title{
Year 2011
}

Gsmarena (2011b) reported much better performance during Q1, 2011 and quoted that $\mathrm{HTC}$ is strengthening its position by buying 82 patents and filed 14 patent applications to add patents to its wireless portfolio of patents. HTC was also planning to hire 100 people for its marketing, operation and R\&D divisions. HTC's earning per share was NT\$ 18.36 during Q1, 2011 .Gsmarena (2011c) cited three smartphones, i.e., Desire HD, Sensation and Thunderbolt droids for the success of HTC during Q2, 2011. HTC's EPS reached NT\$21.69 during $2^{\text {nd }}$ quarter,2011. Nagpal (2011) reported strong brand recognition, leading product portfolio and expanded distribution channels are main factors for growth of HTC during Q3,2011. This quarter EPS of HTC was highest at NT\$ 22.07.Domanico (2012) reported that performance of HTC was less than expectation during Q4, 2011 and its EPS declined to NT\$13.06. This was beginning of the downfall of HTC.

\section{Year 2012}

Wauters (2012) mentioned intensive rivalry in the smartphone business and slowing global economy are responsible for declining performance of the company during Q1, 2012.Jeff (2012a) reported 58\% fall in HTC profit during Q2, 2012 in comparison to Q2, 2011. However, there is an increase in profit in comparison to Q1 2012. Jeff (2012b) reported further reduction in revenue and profits during Q3 2012 and said that HTC is hoping for better results in the next quarter with new launches of Windows Phone 8X and Windows Phone $8 S$ handsets, along with the HTC One X+. Abent (2013) reported that HTC saw good performance in Japan and Taiwan during Q4, 2012. It is also reported that sell of HTC achieved the targets in US and China. 
Singh N.P.: HTC-May Survive in Bipolar World

\section{Year 2013}

Haselton (2013) reported that HTC profit in Q1, 2013 was merely US\$2.88 million in comparison to 151 million during Q1,2012. HTC is betting on new HTC One smartphone.Epstein (2013) mentioned that HTC One performance was up to the satisfaction during Q2, 2013. This is the reason for better performance in comparison to Q1, 2013. HTC has gained market share in China due to HTC One and HTC had taken up many initiatives to improve its performance. Martonik (2013a) reported that HTC has posted an operating loss of over $\$ 101$ million during Q3, 2013 even with better sale of HTC One.Peter (2014) quoted HTC's CFO who said that company need to add more low-end and mid-range smartphone during 2014 to arrest declining performance of the company. Jeff (2014) reported that Q4, 2013 was also a quarter of losses for HTC and said that HTC had to focus on building a compelling mid-range portfolio in the price range of $\$ 150-300$ price range. Tsuki (2014) reported that during 2013 HTC targeted high end phone market which is dominated by Samsung and Apple. Sony and LG are also struggling in this segment for their share. HTC is strategy to compete in this segment is not well crafted in terms of price and quality of devices. The year identified the inadequate product range with HTC.

\section{Year 2014}

Epstein (2014a) stated that HTC recorded big decline in its revenue during Q1, 2014. It was US $\$ 1$ billion. Company also incurred a loss of US $\$ 62$ Million. However, HTC reported that declining trend in revenue is reversed by HTC during March 2014 after 28 months. Ku (2014a) also mentioned that HTC is betting on the demand for its new products, including flagship HTC One [M8] and mid-tier flagship Desire 816. Its losses are as expected by the company for quarter 1, 2014.Epstein (2014c) reported that in Q2, 2014 company recorded a profit of US $\$ 75$ Million but increase in revenue was not substantial. It reaches US\$2.2/2.17/2.05billion. Increase in profit was due to cost cutting measures taken by HTC. Ku (2014b) also reported that its operating profit surpassed the estimates during Q2, 2014. Triggs (2014) connected the performance with good market presence of HTC One (M8) in US \& Europe, HTC One (mini 2) in Europe, HTC One (M8) \& Desire 816 in Taiwan. Lomas (2015) stated that HTC could not keep momentum of Q2, 2014. It is losing both revenue and profits during Q3, Q4 2014. It is betting now on periscope camera accessory for smartphones 'Re", HTC Desire Eye, and One Mini 2.

\section{Year 2015}

Jonnalagadda (2015) quoted that HTC fortunes have further declined during Q1, 2015 but its performance was better in comparison to Q1, 2014. He also mentioned that HTC is betting on One M9 in the U.S. and European markets, 
Singh N.P.: HTC- May Survive in Bipolar World

and One M9+ and One E9+ in Asian markets. Timotato (2015)reported loss of US\$ 260 Million during Q2, 2015 and revenue of mere US\$ 1.07 billion. Lucic (2015) reported revenue as US\$1.076 Billion and per share loss of NT\$ 9.70 as per the expectation of HTC. HTC is developing 'Aero' device as part of its new and innovative camera technology and it may help HTC in its survival.Stefan (2015)quoted operating losses of US\$138 Million during Q3, 2015 with revenue of mere US $\$ 0.659$ billion. It is expected that company will announce major job cut in days to come and prove to be worthless as commented by many experts.

Table6 (a): Quarterly Revenue (US\$ Billion) and Profit/Loss (US\$ Million) of HTC

\begin{tabular}{|c|c|c|c|c|}
\hline $\begin{array}{c}\text { Quarter/ } \\
\text { Year }\end{array}$ & Revenue & Profit/Loss & $\begin{array}{l}\text { Earnings Per } \\
\text { Share (NT\$) }\end{array}$ & Source \\
\hline Q1 2010 & 1.19 & $158[\mathrm{P}]$ & - & Malik (2010) \\
\hline Q1 2010 & 1.15 & $152[\mathrm{P}]$ & 6.38 & Kendrick (2010) \\
\hline Q1 2010 & 1.2 & $160[\mathrm{P}]$ & US\$ 0.20 & Gsmarena (2010) \\
\hline Q2 2010 & 1.88 & $268[\mathrm{P}]$ & 11.17 & Kendrick (2010) \\
\hline Q3 2010 & 2.45 & $360[\mathrm{P}]$ & 13.60 & Savov (2010) \\
\hline Q4 2010 & 3.57 & $514[\mathrm{P}]$ & 18.61 & Gsmarena (2011a), \\
\hline Q1 2011 & 3.60 & $517[\mathrm{P}]$ & 18.36 & Gsmarena (2011b), QR \\
\hline Q2 2011 & 4.32 & $608[\mathrm{P}]$ & 21.69 & Gsmarena (2011c), QR \\
\hline Q3 2011 & 4.54 & $624.6[\mathrm{P}]$ & 22.07 & Nagpal (2011) \\
\hline Q4 2011 & 3.48 & $144.6[\mathrm{P}]$ & 13.06 & Domanico (2012) \\
\hline Q1 2012 & 2.30 & $151.0[\mathrm{P}]$ & 5.35 & Wauters (2012), QR \\
\hline Q2 2012 & 3.04 & $247.0[\mathrm{P}]$ & 8.90 & Jeff $(2012 a), Q R$ \\
\hline Q3 2012 & 2.397 & $133.0[\mathrm{P}]$ & 4.70 & Jeff $(2012 b)$ \\
\hline Q4 2012 & 2.03 & $34.0[\mathrm{P}]$ & 1.21 & Abent (2013) \\
\hline Q1 2013 & 1.45 & $2.88[\mathrm{P}]$ & 0.10 & Haselton (2013) \\
\hline Q2 2013 & 2.40 & $41.70[\mathrm{P}]$ & 1.50 & Epstein (2013) \\
\hline Q3 2013 & 1.60 & $101.30[\mathrm{~L}]$ & $-3.58(0.12$ US $\$)$ & Martonik (2013a) \\
\hline Q4 2013 & 1.42 & $10.20[\mathrm{P}]$ & 0.38 & Peter (2014), Jeff (2014) \\
\hline Q1 2014 & 1.00 & $62.00[\mathrm{~L}]$ & -2.28 & Epstein (2014a), QR, Ku (2014a) \\
\hline Q2 2014 & $2.20 / 2.05^{3}$ & $75.00 / 80[\mathrm{P}]$ & 2.74 & Epstein (2014c), QR, Triggs (2014) \\
\hline Q3 2014 & 1.38 & $19.70[\mathrm{P}]$ & 0.78 & Lomas (2015), QR \\
\hline Q4 2014 & 1.50 & $14.70[\mathrm{P}]$ & 0.57 & Lomas (2015) \\
\hline Q1 2015 & 1.30 & $11.00[\mathrm{P}]$ & 0.43 & Jonnalagadda (2015) \\
\hline Q2 2015 & $1.07^{1} / 1.076$ & $260.00[\mathrm{~L}]$ & -9.70 & Timotato (2015), Lucic (2015) \\
\hline Q3 2015 & $0.659^{2}$ & $138.00[\mathrm{~L}]$ & NT\$-5.85 to -5.51 & Stefan (2015) \\
\hline
\end{tabular}

Source: 1-Unaudited data, 2- Operating Loss, 3- there are variations in profit figures for different sources, [P]-Profit, [L]- Loss, QR-Quarterly Report of HTC.

The quarterly revenue, profits, and earning per shares (EPS) in Taiwan currency are given in table $6(\mathrm{~b})$. The major source of data is quarterly reports of HTC except for few quarters. The objective to create data in Taiwan dollar was to confirm trends of data given in table 6(a). Tan (2010) mentioned that HTC could collaborate with T-mobile USA with HTC HD2, and Sprint with 
Singh N.P.: HTC- May Survive in Bipolar World

HTC EVO (4G handset for WiMAX technology) but such initiative is missing in later years.

Table 6 (b):Quarterly Revenue (NT\$ Billion), Profit/Loss (NT\$ Billion) and EPS (NT\$) of HTC

\begin{tabular}{|c|c|c|c|c|}
\hline Quarter/Year & Revenue & Profit/Loss & EPS & Source \\
\hline Q1 2010 & $37.69 / 37.70$ & 4.99/5.00 [P] & $6.38 / 6.42$ & $\begin{array}{c}\text { Kendrick (2010), Tan } \\
(2010)\end{array}$ \\
\hline Q2 2010 & 60.53 & $8.64[\mathrm{P}]$ & 11.17 & $\begin{array}{c}\text { Kendrick (2010), } \\
\text { NR(2010a) }\end{array}$ \\
\hline Q3 2010 & 75.84 & $11.09[\mathrm{P}]$ & 13.61 & NR (2010b) \\
\hline Q4 2010 & 104.00 & $14.59[\mathrm{P}]$ & 18.01 & NR (2011) \\
\hline Q1 2011 & 104.16 & $14.83[\mathrm{P}]$ & 18.36 & QR \\
\hline Q2 2011 & 124.40 & $17.52[\mathrm{P}]$ & 21.69 & QR \\
\hline Q3 2011 & 135.82 & $18.68[\mathrm{P}]$ & 22.07 & QR \\
\hline Q4 2011 & 101.42 & $10.94[\mathrm{P}]$ & 13.06 & QR \\
\hline Q1 2012 & 67.79 & $4.47[\mathrm{P}]$ & 5.35 & QR \\
\hline Q2 2012 & 91.04 & $7.40[\mathrm{P}]$ & 8.90 & QR \\
\hline Q3 2012 & 70.20 & $3.90[\mathrm{P}]$ & 4.70 & QR \\
\hline Q4 2012 & 60.00 & $1.00[\mathrm{P}]$ & 1.21 & QR \\
\hline Q1 2013 & 42.80 & $0.85[\mathrm{P}]$ & 0.10 & QR \\
\hline Q2 2013 & 70.70 & $1.25[\mathrm{P}]$ & 1.50 & QR \\
\hline Q3 2013 & 47.00 & $3.00[\mathrm{~L}]$ & 3.58 & QR \\
\hline Q4 2013 & 42.90 & $0.31[\mathrm{P}]$ & 0.38 & QR \\
\hline Q1 2014 & 33.10 & $1.88[\mathrm{~L}]$ & 2.28 & QR \\
\hline Q2 2014 & 65.10 & $2.30[\mathrm{P}]$ & 2.74 & QR \\
\hline Q3 2014 & 41.90 & $0.60[\mathrm{P}]$ & 0.78 & QR \\
\hline Q4 2014 & 47.90 & $0.50[\mathrm{P}]$ & 0.57 & QR \\
\hline Q1 2015 & 41.50 & $0.36[\mathrm{P}]$ & 0.43 & QR \\
\hline Q2 2015 & 33.00 & $8.00[\mathrm{~L}]$ & 9.70 & QR \\
\hline Q3 2015 & 21.40 & $4.50[\mathrm{~L}]$ & 5.41 & QR \\
\hline
\end{tabular}

Source: NR - News Release, QR- Quarterly Report

HTC's monthly revenue (NT\$ million) are compiled in table 6๑. This is again to confirm trends of quarterly data from a different source. Table 6๑) summarizes a 10-year story of HTC's growth and downfall. Nickinson (2009) cited that Touch Diamond-series phones and T-Mobile's Android-based G1 are responsible for growth of HTC during 2008. He also mentioned that HTC is planning about 10 new Windows Mobile and Android devices and is looking to grow revenue by 20 percent. In recent years, such announcements of big portfolio are missing from HTC. Table 6(d) consists of yearly revenue in US $\$$ and contain data for few more number of years. 
Singh N.P.: HTC- May Survive in Bipolar World

Table 6(c): HTC Monthly Revenue (in NT\$ Million)

\begin{tabular}{|c|c|c|c|c|c|c|c|c|c|c|}
\hline Month & 2015 & 2014 & 2013 & 2012 & 2011 & 2010 & 2009 & 2008 & 2007 & 2006 \\
\hline January & 12.3 & 9.7 & 15.5 & 16.6 & 35.0 & 11.1 & 10.0 & 12.0 & 7.9 & 7.2 \\
\hline February & 9.2 & 7.2 & 11.4 & 20.3 & 32.1 & 10.1 & 9.2 & 9.6 & 6.6 & 7.8 \\
\hline March & 20.0 & 16.2 & 15.9 & 30.9 & 37.0 & 16.4 & 12.4 & 11.0 & 9.1 & 9.0 \\
\hline April & 13.5 & 22.1 & 19.6 & 31.0 & 38.7 & 18.0 & 11.4 & 11.8 & 9.1 & 7.6 \\
\hline May & 10.8 & 21.1 & 29.0 & 30.0 & 40.6 & 18.7 & 12.5 & 10.9 & 8.0 & 8.3 \\
\hline June & 8.7 & 21.9 & 22.1 & 30.0 & 45.0 & 23.9 & 14.3 & 11.8 & 9.8 & 10.1 \\
\hline July & 7.4 & 10.6 & 15.7 & 25.0 & 45.1 & 24.6 & 10.8 & 11.4 & 9.0 & 8.9 \\
\hline August & 6.9 & 14.5 & 13.2 & 24.0 & 45.3 & 24.2 & 11.3 & 12.7 & 9.5 & 8.6 \\
\hline Septembe & 7.1 & 16.7 & 18.2 & 21.1 & 44.1 & 27.1 & 11.8 & 13.7 & 10.6 & 8.9 \\
r & & & & & & & & & & \\
\hline October & 8.9 & 15.8 & 14.9 & 17.2 & 44.1 & 32.4 & 12.7 & 16.0 & 13.1 & 10.7 \\
\hline November & 10.3 & 16.9 & 15.5 & 21.2 & 31.0 & 38.5 & 14.3 & 17.8 & 14.5 & 10.9 \\
\hline December & - & 15.2 & 12.4 & 21.6 & 26.4 & 33.1 & 14.1 & 13.6 & 11.4 & 8.1 \\
\hline Total & 115. & 187. & 203. & 289. & 465. & 278. & 144. & 152. & 118. & 106. \\
& 2 & 9 & 4 & 0 & 8 & 1 & 9 & 6 & 6 & 1 \\
\hline
\end{tabular}

Source: http://investors. htc.com/phoenix.zhtml?c=148697\&p=irol-reportsMonthlyRevenues Notes: The YoY change in 2006, 2007, 2008, 2009, 2010, 2011, 2012, 2013, 2014 and, 2015 is () $31.42 \%$, (-) $10.50 \%$, (-) $22.27 \%, 5.3 \%$, (-) $47.95 \%$, (-) $40.15 \%$, (-) $37.95 \%$, (-) $28.60 \%$, (-) $7.62 \%$ and, (-) $33.32 \%$ respectively.

Table 6(d): Yearly HTC Revenue (in Billion US\$)

\begin{tabular}{|c|c|c|c|}
\hline Year & Revenue & Profit & Source $^{1}$ \\
\hline 2003 & 0.67 & 0.012 & Annual Report 2008 $^{-1.11}$ \\
\hline 2004 & 2.24 & 0.022 & Annual Report 2008 \\
\hline 2005 & 3.22 & 0.055 & Annual Report 2008 \\
\hline 2006 & 3.65 & 0.10 & Annual Report 2008 \\
\hline 2007 & 4.65 & 0.14 & Annual Report 2008 \\
\hline 2008 & 4.41 & 0.16 & Annual Report 2010 \\
\hline 2009 & 8.39 & 0.14 & Annual Report 2010 \\
\hline 2010 & 13.89 & 0.24 & Annual Report (2015 \\
\hline 2011 & 8.26 & 0.36 & Annual Report 2015 \\
\hline 2012 & 5.93 & 0.17 & Annual Report 2015 \\
\hline 2013 & 5.33 & 0.10 & Annual Report 2015 \\
\hline 2014 & 1.36 & 0.095 & Annual Report 2015 \\
\hline 2015 Q1 & $1.50-1.67$ & - & Jonnalagadda (2015) \\
\hline 2015 Q2 [E] & $1.48-1.64$ & - & Jonnalagadda (2015) \\
\hline 2015 Q2 [E] & $1.07-1.17$ & Revised & Boxall (2015) \\
\hline 2015 Q2 [E] & 1.07 (unaudited) & $260.00[\mathrm{~L}]$ & Boxall (2015) \\
\hline 2015 Q2 & 0.659 & $138.00[\mathrm{OL}]$ & Simotato (2015) \\
\hline 2015 Q3 & & & Stefan (2015) \\
\hline
\end{tabular}

Source: 1-Annual reports are available on HTC website. $O L=$ Operating Losses 
Singh N.P.: HTC- May Survive in Bipolar World

\section{Ways to Recover for HTC}

(i) Innovation: Amadeo (2015) mentioned that HTC promised a new "hero" smartphone in October, 2014. It is a significant improvement in innovation and design for the next flagship model next year. Banbury and Mitchel (1995) said that incremental innovations makes good impact on market share and business survival in industry which has moderate switching costs for the buyers. HTC may introduce incremental innovations rather than looking for major breakthrough which may not be possible in smartphone manufacturing industry.

(ii) Cost Cutting: HTC want to dilute its software division with a view to cut cost (Amadeo (2015)). It is a good idea. It must learn lessons from Nokia's strategy of being both hardware as well software vendor at a time when world was moving closer to Android OS and it failed miserably due to Symbian operating system (Singh (2014)). HTC must concentrate on hardware and let Google and Microsoft take care of OS and other software components. HTC may follow policies of Lenovo in managing loss making businesses.

(iii) Expansion: HTC may produce other devices such as Camera and Vive VR Headset to have wider portfolio (Amadeo (2015), Boxall (2015)). It is a good idea but needs time for proper planning and to create cost effective strategy.

(iv) Moving to South East Asia: Liu(2015) reported that HTC may move its factories to Indonesia to reduce the cost of production but it is denied by HTC. It is a good idea to cut the cost by moving to low cost areas/countries for production and do innovation in home country.

(v) Mid-Range Portfolio: Jeff (2014) mentioned that HTC will focus on building a compelling mid-range portfolio in the price range of $\$ 150$ 300 price range. On the other hand, Vince (2015) reported that Samsung had lost ground in the low-end and mid-range smartphone spectrum due to fierce competition by Chinese makers. If HTC can compete with Chinese makers than it must concentrate on midrange portfolio. However, it will be very difficult for HTC but it is not impossible.

(vi) No Selling-Off: It is reported that HTC buyer could be mobile phone maker (Samsung, Apple, Lenovo, LG, Xiaomi, Huawei etc.), PC maker (Asus/ Acer/ Dell/ HP), Microsoft, Google, Facebook, Amazon, Blackberry, OnePlus etc. There were lots of rumors about 
Singh N.P.: HTC-May Survive in Bipolar World

ASUS buying HTC. These are denied by HTC. HTC must sustain its present status and innovate with existing technology or create new partnership for innovation and come back in next two to three years. HTC should not share information on its mergers with others and selling off of its assets.

(vii) Collaborating with Entrepreneurs: It will be better for HTC to collaborate with new technology startups for innovation, research, and development. It will help in two ways. HTC will get rid of internal innovation stagnation if any. Secondly, it will create synergies between different mind sets.

\section{Research Question}

Based on the data presented in earlier sections of the research paper, this section presents possible answers to the research questions in the context of HTC downfall.

Research Question 1:Will HTC be able to survive in the face of recent downfall and fierce completion in the market?

Neil Mawston said "HTC is struggling against ambitious Chinese and Indian brands in the low and middle tiers, while Apple and even Samsung continue to provide serious challenges in the high-end"(Jennings (2014)). On the face of performance statistics of the company it looks that HTC may not survive the competition. If HTC can maintain its present status with no decline further for 3 to 4 quarters, then it will beat the competition and will bounce back. On the other hand, if the management of HTC sends signals of mergers or selling then it will be end of journey for HTC.

Proposition/ Research Question 2: Does the size of home country markets matter for success?

Yes, it matters for success since local device makers understand pulse of buyers better than outsiders. If one compares home market for Nokia (5.4 million people of Finland), HTC (23.4 Million people of Taiwan), and Samsung (50 million people of South Korea) for success or failure then statistics are in favor of concluding that size of home country market makes difference. Nokia mobile phone business no more exists, it is taken over by Microsoft (Singh (2014)). HTC is losing more in the domestic market in comparison to international market and is on the verge of collapse. Samsung is still growing but losing growth trajectory.

Proposition/ Research Question 3: High technology market has place only for few successful international brands. 
Singh N.P.: HTC- May Survive in Bipolar World

It is reported by many experts that smartphone market has room for 4 to 5 international brands and this can be further ascertain by data presented in table 1, 2, 3 given in earlier sections of the research paper. It is further reported that life cycle of smart phones devices is small which is evident from the price reduction of older devices with the launch of new upgrades. If one does not push large portfolio (combination of hardware and software) of devices quickly for all segments of market one loses its market share and if one is too aggressive in pushing new devices, it eats profits due to high manufacturing cost. Unbalanced approach makes companies in others category. It is true in the present context of smartphone business.

Proposition/ Research Question 4: High growth of a company in high tech domain results in to early downfall.

In case of HTC it is true. Alone HTC data is not sufficient to draw conclusion. One needs to analyze data of Nokia, Motorola, and few others to confirm the statement of this research question.

Proposition/ Research Question 5: Will expanded device portfolio help HTC in managing the confidence of the investors in near future?

Certainly it will help HTC in managing confidence of investors. Large device portfolio will help HTC to devise better marketing strategy and failure of few devices due to not so right combination of components or not so appropriate features of software will not impact its market share and profitability. It will also help in reducing overall negativity of HTC devices and customer will have more choices.

\section{Proposition/ Research Question 6: Lack of innovation by HTC is responsible for its downfall.}

It is evident from the fact that HTC does not have a big basket of patents like Motorola or Nokia. Motorola market value was because of Patents (Singh (2015)). This is not true in case of HTC. Apple had filed lawsuit against HTC. HTC is to settle patent issue with Nokia. It can be taken as surrogate factor that HTC suffer from lack of appropriate effort in innovation. It could be one of factor responsible for the downfall of HTC.

Proposition/ Research Question 7: Android's internal rivalry is responsible for its downfall.

Smartphone success and failure depend on hardware as well as software which include mainly OS and application software. In present day context one of the important processes to develop software is integration of many software components to have ultimate needed software (OS or Application). In addition, software's are sold in the form of different versions. Differentiating among large number of versions of software (OS or Application) is sometimes 


\section{Singh N.P.: HTC- May Survive in Bipolar World}

not possible for OEMs. Android's internal rivalry is reported by only one expert as a factor responsible for the downfall of HTC but it could be a reason for failure. Android may be treating Samsung with priority in comparison to other makers of smartphone in term of quality of software's.

\section{Proposition/ Research Question 8: First mover advantage does not work in all cases.}

HTC was first to use Android operating systems. It means HTC must be benefitted by first mover advantage. But it was not in HTC case. HTC lost this advantage very quickly. It is in support of proposition that first mover advantage did not work in all cases.

\section{Conclusions}

Miller (1990) observed that "success leads to specialization and exaggeration, to confidence and complacency to dogma and ritual". He also made a candid comment that it is the strength of companies that lead to their downfall. HTC was working in specialized domain. Its initial growth was exaggerated by media. Every move of HTC was described as right move. This might have converted in to over confidence in the mind set of leadership at different levels in HTC which at some stage got converted in to complacency. Having attained this stage media turned hostile to HTC and started finding fault with HTC management and reported every move either as late or not in right perspective.

Experts have concluded that smartphone market will absorb only 3 to 4 vendors in tier-1 category. The market still has four to five players in tier-1 category. These are Samsung, Apple, Huawei, Xiaomi, and Lenovo. HTC exited from this group. Many reasons are cited for exit of HTC from tier-I category or even tier-II category in earlier sections of the research paper. In recent past every move of HTC is unsuccessful in the eyes of media and also for ultimate business outcome. Present state of business in HTC is making it worthless as reported in the print / electronic media. Still going by statements of leadership and not much reporting in media with respect to merger of HTC with other smartphone makers or selling off HTC to smartphone makers or software developers or other companies in eco-system indicates that HTC may survive as smartphone makers of in "other category" in a bipolar world of smartphone makers. With changing market dynamics, one of the leading smartphone makers will certainly commit some mistake in next few years or geopolitical event may force any one of them to lose its place, HTC may fill that place. To fulfill its dream HTC must first concentrate to regain domestic market and look for new markets wherein competition is weak. HTC needs to 
Singh N.P.: HTC- May Survive in Bipolar World

develop an excellent product portfolio to compete and to arrest existing decline of the company.

\section{References}

Abent, E. (2013). HTC's Q4 2012 results have revenue at NT\$60 billion. February $04 .$. Retrieved from www.slashgear.com/htcs-q4-2012-results-have-revenue-at-nt60billion-04268006/ 2015 Nov 18.

Ahonen, T.T. (2013). Final Q4 numbers and full year 2012 stats for smartphone market share: Top 10 manufactures, Top OS platforms, Top installed bases (revised and corrected). February 13.. Retrieved from http://communitiesdominate.blogs.com/brands/2013/02/final-q4-numbers-and-full-year-2012-statsfor-smartphone-market-shares-top-10-manufacturers-top-os-p.html 2015 Nov 21.

Ahonen, T.T. (2014). Final 2013 samrtphones market share number: Full year and quarterly Q4 data by top brands, plus OS shares, plus installed base. February 13.. Retrieved from http://communitiesdominate.blogs.com/brands/2014/02/final-2013-smartphone-market-sharenumbers-full-year-and-quarterly-q4-data-by-top-10-brands-plus-os-.html 2015 Nov 21.

Amadeo, R. (2015). Help this company: A post-mortem of HTC's horrible start to 2015. July 09. Retrieved from http://arstechnica.com/gadgets/2015/07/help-thiscompany-a-post-mortem-of-htcs-horrible-start-to-2015/2015 Nov 21.

-AP. (2015). Taiwan's stock exchange removes HTC from blue chip index. September 21.. Retrieved from http://timesofindia.indiatimes.com/tech/tech-news/Taiwansstock-exchange-removes-HTC-from-blue-chip-index/articleshow/49043642.cms 2015 Nov 21.

Arthur, C. (2010). Visualising the smartphone market change: Android leaps, Nokia wobbles. November 10.. Retrieved from http://www.theguardian.com/technology/ blog/ 2010/nov/10/smartphone-market-growth-gartner-q3-2010 2015 Oct 10.

Banbury, M.C., \& Mitchel, W. (1995). The effect of introducing important incremental innovations on market share and business survival. Strategic Management Journal, 16, 161-182.

Barrett, B. (2015). HTC's Epic Tailspin Isn't Even Its Fault. November 11.. Retrieved from http://www.wired.com/2015/08/htc-financial-trouble/ 2015 Nov 20.

Beaver, L. (2015). How HTC's market share collapsed. August 12.. Retrieved from http://www.businessinsider.in/How-HTCs-market-sharecollapsed/articleshow/48456710.cms 2015 Nov 21.

Blandford, R., \& Leitchfield, S. (2012). Q2, 2012 statistics released by IDC, 154 million smartphones sold. July 27. Retrieved from http://www.allaboutsymbian.com/flow/item/15365_Q2_2012_statistics_released_ by.php 2015 Oct 25.

Boxall, A. (2015). HTC dramatically slashes sales estimates, but it has a plan to get things back on track. June 08.. Retrieved from http://www.digitaltrends.com/mobile/htc-q2-2015-revised-revenue-news/ 2015 Nov 21. 


\section{Singh N.P.: HTC- May Survive in Bipolar World}

Brian, M. (2010). HTC looking to ship 8. 5 million smartphones in Q4 2010. October 25.. Retrieved from http://thenextweb.com/mobile/2010/10/25/htc-looks-to-ship8-5-million-smartphones-in-q4-2010/ 2015 Nov 18.

Canalys, (2012). Sony and HTC overtake RIM and Nokia in smart phones. November 08.. Retrieved from http://www.canalys.com/newsroom/sony-and-htc-overtakerim-and-nokia-smart-phones 2015 Nov 21.

Chawla, M. (2014). Why did Lenovo buy Motorola and not HTC?. January $31 .$. Retrieved from http://economictimes.indiatimes.com/news/international/ business/why-did-lenovo-buy-motorola-and-not-htc/articleshow/29663984.cms 2015 Oct 25.

-Counterpoint Research. (2014). Market Monitor: Handset and Smartphone market Q2. Retrieved from http://www.counterpointresearch.com/marketmonitor2q14 2015 Dec 25.

Deckor, S., \& Wang, C. (2014). HTC to pay Nokia royalties to end smartphone patent flight. $\quad$ February $\quad 08 . . \quad$ Retrieved from http://www.bloomberg.com/news/articles/2014-02-07/htc-to-pay-nokia-royaltiesto-end-smartphone-patent-fight 2015 Dec 26.

de Guzman, J. (2013). Samsung Is the Reason Behind HTC's Loss and BlackBerry's Shut Down. October 05.. Retrieved from http://www.onlinegadgetstore.com/9108-samsung-reason-htcs-loss-blackberrysshut/ 2015 Nov 15.

Domanico, A. (2012). HTC's Q4 2011 revenue of \$3. 48 billion falls short of analyst projections, Q1 2012 projection revised downward. February 08.. Retrieved from http://androidandme.com/2012/02/news/htcs-q4-2011-revenue-of-3-48-billionfalls-short-of-analyst-projections-q1-2012-projection-revised-downward/ 2015 Nov 18.

Edwards, J. (2015). One statistic tells you why HTC collapsed and why Android is in much trouble. august 10.. 2015 Nov 18.

Epstein, Z. (2010). HTC reports record revenue in Q4. October 29.. Retrieved from http://bgr.com/2010/10/29/htc-reports-record-revenue-in-q4/ 2015 Nov 18.

Epstein, Z. (2013). HTC's Q2 profit tumbles as company forecasts first ever loss for Q3. July 30.. Retrieved from http://bgr.com/2013/07/30/htc-earnings-q2-2013/ 2015 Nov 18.

Epstein, Z. (2014). HTC's revenue finally rises in March, but can't stop Q1 loss. April 07.. Retrieved from http://bgr.com/2014/04/07/htc-earnings-q1-2014/ 2015 Nov 18.

Epstein, Z. (2014). HTC One (M8) shipments seen reaching 3-5 million in Q2. April 16. Retrieved from http://bgr.com/2014/04/16/htc-one-m8-sales-q2/ 2015 Nov 21.

Epstein, Z. (2014). HTC returns to profit in Q2 as steep climb begins. July 03. Retrieved from http://bgr.com/2014/07/03/htc-earnings-q2-2014-unaudited/ 2015 Nov 18.

Griffith, (2013). The rise and fall of HTC. September 02.. Retrieved from http://www.managementtoday.co.uk/features/1210101/the-rise-fall-htc/ $2015 \mathrm{Dec}$ 25.

-Gsmarena. (2010). HTC starts 2010 with a profitable first quarter. April 07.. Retrieved from www.gsmarena.com/htc_starts_2010_with_a_profitable_first_quarter-news1559.php 2015 Dec 16. 
Singh N.P.: HTC- May Survive in Bipolar World

-Gsmarena. (2011). HTC closing a successful fourth quarter 2010, January 24. Retrieved from http://www.gsmarena.com/ htc_closing_a_successful_fourth_quarter_2010-news-2249.php 2015 Nov 21.

-Gsmarena. (2011). HTC profits soar in Q1, Number of phones shipped triples. April 29.. Retrieved from http://www.gsmarena.com/ htc_profit_soars_number_of_phones_shipped_triples-news-2578.php 2015 Nov 18.

-Gsmarena. (2011). HTC posts record profit, revenue in Q2 2011. July 06.. Retrieved from http://www.gsmarena.com/ htc_posts_record_profit_revenue_in_q2_expects_more_of_the_same_in_q3news-2859.php 2015 Nov 18.

Haselton, T. (2013). HTC profits slumps in Q1 2013. May 02.. Retrieved from www.technobuffalo.com/2013/05/02/htc-q1-2013-earnings-2/ 2015 Nov 18.

Hruska, J. (2015). HTC declared effectively worthless: LG's profits margins fall to a penny a phone. August 10.. Retrieved from http://www.extremetech.com/computing/211972-htc-declared-effectivelyworthless-lgs-profit-margins-fall-to-a-penny-a-phone 2015 Dec 25.

Jeff, C. (2012). HTC Q2 2012 financial results reveal profits fallen 58 percent. August 03.. Retrieved from http://unleashthephones.com/2012/08/03/htc-q2-2012financial-results-reveal-profits-fallen-58-percent/ 2015 Nov 18.

Jeff, C. (2012). HTC Q3 2012 results - \$2. 397 billion revenue. October 08.. Retrieved from http://unleashthephones.com/2012/10/08/htc-q3-2012-results-2-397-billionrevenue/ 2015 Nov 18.

Jeff, C. (2014). HTC Q4 2013 results: \$10. 2 million net profit, revenue still declining. February 10.. Retrieved from http://unleashthephones.com/2014/02/10/htc-q42013-results-10-2-million-net-profit-revenue-still-declining/ 2015 Nov 18.

Jennings, R. (2014). HTC's smartphone market share to fall again in 2015: What's up?. November 5.. Retrieved from http://www.forbes.com/sites/ralphjennings/2014/11/05/htcs-smartphone-marketshare-to-fall-again-in-2015-whats-up/ 2015 Dec 19.

Jonnalagadda, $\mathrm{H}$. (2015). HTC records $\$ 1$. 3billion revenue, net profit of $\$ 11$ million in Q1 2015. April 29.. Retrieved from http://www.androidcentral.com/htc-records13-billion-revenue-net-profit-11-million-q1-2015 2015 Nov 18.

Kendrick, J. (2010). Android helps HTC sales jump 63\% in second quarter. July $06 .$. Retrieved from https://gigaom.com/2010/07/06/htc-posts-66-revenue-increasein-june/ 2015 Nov 21.

Kessler, D. (2015). HTC has $\$ 1.5$ billion in the bank, but investors think the company's worth even less.. August 10.. Retrieved from http://www.androidcentral.com/htcs-stock-has-fallen-point-investors-thinkcompanys-near-worthless 2015 Oct 12.

$\mathrm{Ku}, \mathrm{H}$. (2014). HTC corp posts NT\$1. 88bn Q1 loss. April 08.. Retrieved from http://www.taipeitimes.com/News/biz/archives/2014/04/08/2003587509 2015 Nov 23.

$\mathrm{Ku}, \mathrm{H}$. (2014). HTC posts NT\$2. 26. 88bn net profit for Q2. July 04.. Retrieved from http://www.taipeitimes.com/News/biz/archives/2014/07/04/2003594273 2015 Dec 23.

Liu, J. (2015). HTC now planning to lay off 600 employees in Taiwan in October. September 01.. Retrieved from http://www.chinapost.com.tw/business/companyfocus/2015/09/01/444774/HTC-now.htm 2015 Nov 11. 
Singh N.P.: HTC- May Survive in Bipolar World

Lomas, N. (2015). HTC reports slender \$14. 7M profit, Revenue growth in Q4 2014. January 06.. Retrieved from http://techcrunch.com/2015/01/06/htc-q4-2014/ 2015 Nov 18.

Lucic, K. (2015). HTC's Q2 Financial Results Are In, And They're Not Good. July 06.. Retrieved from http://www.androidheadlines.com/2015/07/htcs-q2-financialresults-theyre-not-good.html 2015 Oct 10.

Malik, O. (2010). For HTC, Android brings growth \& profits. April 06.. Retrieved from https://gigaom.com/2010/04/06/htc-earnings/ 2015 Nov 21.

Malik, O. (2013). HTC One and the harsh reality of the Android ecosystem. May $22 .$. Retrieved from https://gigaom.com/2013/05/22/htc-one-and-the-harsh-reality-ofthe-android-ecosystem/ 2015 Nov 21.

Martonik, A. (2013). HTC announces \$101 million operating loss for Q3 2013. October 03.. Retrieved from http://www.androidcentral.com/htc-announces-101-millionoperating-loss-q3-2013 2015 Nov 18.

Miller, D. (1990). The Icarus paradox: How exceptional companies bring about their own downfall. Harper Business.

Millward, S. (2015). The rise and fall of HTC (Infographics). September 02.. Retrieved from https://www.techinasia.com/htc-rise-and-fall-infographic 2015 Dec 25.

Mobithinking, (2012). 2011 handset and smartphone sales statistics worldwide: The big picture. February 10.. Retrieved from https://mobiforge.com/researchanalysis/2011-handset-and-smartphone-sales-statistics-worldwide-big-picture 2015 Nov 27.

Myeong-Cheol, P., Dong-hoon, Y., Changi, N., \& Young-Wook, H. (2002). Mergers and acquisitions in the telecommunications industry: Myths and Reality. ETRI Journal, 24(1), 56-64.

-Mynewsdesk. (2013). 14 largest mobile manufactures for Q2 2013 reveled. August 31.. Retrieved from http://www.mynewsdesk.com/uk/news/14-largest-mobilemanufacturers-for-q2-2013-revealed-65379 2015 Nov 21.

Nagpal, B. (2011). HTC releases profits reports for quarter 3 profit up 68 percent. November 02.. Retrieved from http://www.igyaan.in/17508/htc-releases-profitreports-quarter-3-profit-68-percent/ 2015 Nov 18.

HTC June 2010 sales report. (2010). News Release, July 6. Retrieved from http://media.corporate-ir.net/media_files/irol/14/148697/ MonthlyRevenues/NR100706E.pdf 2015 Dec 25.

HTC September 2010 consolidated sales report. (2010). News Release, October $6 .$. Retrieved from http://media.corporate-ir.net/media_files/ irol/14/148697/MonthlyRevenues/NR-101006E.pdf 2015 Dec 25.

HTC announced unaudited revenue for December 2010 and 2010 financial results, EPS after tax reached NT\$48.24. (2011). News Release, January 6.. Retrieved from www.media.corporateir.net/media_files/irol/14/148697/MonthlyRevenues/NR110106E_LkAJMjAf35bF_aA6fkIJMJFDu_UFpDetlAkcN9.pdf 2015 Dec 25.

Nickinson, P. (2009). HTC's revenue up 29 percent for 2008. January 07.. Retrieved from http://www.windowscentral.com/htcs-revenue-29-percent-2008 2015 Nov 21.

Nicole, K. (2012). Android's internal rivalry caused HTC's downfall. February 06.. Retrieved from http://www.androidapps.com/tech/articles/10972-androidsinternal-rivalry-caused-htcs-downfall 2015 Oct 12. 
Singh N.P.: HTC- May Survive in Bipolar World

Peter, K. (2014). HTC announces Q4 2013 financial results: Both revenue and expenses go down. February 10.. Retrieved from http://www.phonearena.com/news/HTC-announces-Q4-2013-financial-results-both-revenue-and-expenses-go-down_id52424 2015 Nov 18.

Riley, D. (2015). Possible end of days for $\bar{H} T C$ as company now valued less than its cash on hand. August 10.. Retrieved from http://siliconangle.com/blog/2015/08/10/possible-end-of-days-for-htc-ascompany-now-valued-less-than-its-cash-on-hand/ 2015 Oct 12.

Savov, V. (2010). HTC grows profits in Q3 to \$360 million, revenue rise to $\$ 2$. $45 \mathrm{~b}$. October 06.. Retrieved from http://www.engadget.com/2010/10/06/htc-growsprofits-in-q3-to-360-million-revenues-rise-to-2-45b/ 2015 Nov 20.

Shah, N. (2014). Market Monitor: Handset and Smartphone market Q3 2014. October 30.. Retrieved from http://www.counterpointresearch.com/marketmonitor2014q3 2015 Dec 25.

Shah, N. (2015). HTC: From Riches to rags. September, 05.. Retrieved from https://www.linkedin.com/pulse/htc-from-riches-rags-neil-shah 2015 Nov 23.

Singh, N.P. (2014). Microsoft Acquired Nokia in Uni-polar Operating System Market. Independent Journal of Management and Production, 5(3), 598-622.

Singh, N.P. (2015). Google Bought and Sold Motorola Mobility-What it means?. International Journal of Business Policy and Strategy Management, In Press.

Sivanandan, A. (2014). HTC's Global Market Share Falls Consistently, Poor Advertising Strategy May Be The Major Cause. November 10.. Retrieved from http://www.ibtimes.com.au/htcs-global-market-share-falls-consistently-pooradvertising-strategy-may-be-major-cause-13866802015 Dec 25.

Sridhar, S. (2012). IDC: Mobile phone market Q1 2012: Samsung, Nokia and Apple top mobile phone vendors by shipments. May 02.. Retrieved from www.fonearena.com/blog/49418/idc-mobile-phone-market-q1-2012-samsungnokia-and-apple-top-mobile-phone-vendors-by-shipments.html 2015 Nov 22.

Statista, (2015). HTC domestic and export smartphone unit sales from 2007 to 2014 (in 1, 000s). Retrieved from http://www.statista.com/statistics/208911/htcsmartphone-sales-since-2007/ 2015 Dec 19.

Stefan, (2015). HTC unsurprisingly posted an operating loss in Q3 2015. October 06.. Retrieved from http://www.gsmarena.com/ htc_unsurprisingly_posted_an_operating_loss_in_q3_2015-news-14319.php 2015 Nov 18.

Taipeitimes, (2013). HTC market share stays low at 3. 1 percent in Q1. May 06. Retrieved

from http://www.taipeitimes.com/News/biz/archives/2013/05/06/2003561541 2015 Nov 21.

Tan, J. (2010). HTC reports rising profit,. April 07.. Retrieved from http://www.taipeitimes.com/News/biz/archives/2010/04/07/2003469971 2015 Oct 1.

Timotato, (2015). HTC posts unaudited Q2 2015 results, \$166M net loss on \$1. 07B of revenue. July 06.. Retrieved from http://www.droid-life.com/2015/07/06/htcposts-unaudited-q2-2015-results-166m-net-loss-on-1-07b-of-revenue/ 2015 Nov 18. 


\section{Singh N.P.: HTC- May Survive in Bipolar World}

Triggs, R. (2014). HTC posts strong Q2 2014 earnings results, but still faces an uncertain future. August 4.. Retrieved from http://www.androidauthority.com/htcq2-2014-earnings-results-413572/ 2015 Dec 24.

Vince, (2015). Trend force: Samsung falls below 25\% market share in Q3 as Chinese competitors grow. October 14.. Retrieved from www.gsmarena.com/trendforce_samsung_falls_below_25_market_share_in_q3 _as_chinese_competitors_gets_fiercer-news-14473.php 2015 Nov 27.

Wauters, R. (2012). HTC posts weak Q1 2012 earnings: Revenue down 35\%, net profit down 70\%. April 06.. Retrieved from http://thenextweb.com/mobile/2012/04/06/htc-posts-weak-q1-2012-earningsrevenue-down-35-net-profit-down-70/

2015

Nov

18. 
